\title{
Enhancement of biohydrogen production rate in Rhodospirillum rubrum by a dynamic CO-feeding strategy using dark fermentation
}

Alberto Rodríguez ${ }^{1,2}$, Natalia Hernández-Herreros ${ }^{1,2}$, José L. García ${ }^{1,3}$ and M. Auxiliadora Prieto ${ }^{1,2^{*}}$ (i)

\begin{abstract}
Background: Rhodospirillum rubrum is a purple non-sulphur bacterium that produces $\mathrm{H}_{2}$ by photofermentation of several organic compounds or by water gas-shift reaction during $\mathrm{CO}$ fermentation. Successful strategies for both processes have been developed in light-dependent systems. This work explores a dark fermentation bioprocess for $\mathrm{H}_{2}$ production from water using $\mathrm{CO}$ as the electron donor.

Results: The study of the influence of the stirring and the initial CO partial pressure $\left(p_{\mathrm{CO}}\right)$ demonstrated that the process was inhibited at $p_{\mathrm{CO}}$ of $1.00 \mathrm{~atm}$. Optimal $p_{\mathrm{CO}}$ value was established in $0.60 \mathrm{~atm}$. CO dose adaptation to bacte-

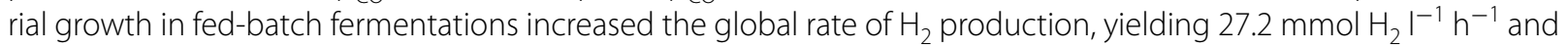
reduced by $50 \%$ the operation time. A kinetic model was proposed to describe the evolution of the molecular species involved in gas and liquid phases in a wide range of $p_{\text {CO }}$ conditions from 0.10 to $1.00 \mathrm{~atm}$.

Conclusions: Dark fermentation in R. rubrum expands the ways to produce biohydrogen from CO. This work optimizes this bioprocess at lab-bioreactor scale studying the influence of the stirring speed, the initial CO partial pressure and the operation in batch and fed-batch regimes. Dynamic CO supply adapted to the biomass growth enhances the productivity reached in darkness by other strategies described in the literature, being similar to that obtained under light continuous syngas fermentations. The kinetic model proposed describes all the conditions tested.
\end{abstract}

Keywords: Hydrogen, Rhodospirillum rubrum, Syngas, Dark fermentation, Kinetic model

\section{Background}

The development of biofuels has multiplied global energy alternatives, aiming the reduction of conventional fossil fuels dependence, carbon footprint and increasing the sustainability of human activities in a context of climate change and depletion of non-renewable resources in the global ecosystem [1]. Global biofuel production reached a record of 154 billion litres in 2018, growing a 7\% yearon-year since 2013, and the future prospects point to an

\footnotetext{
*Correspondence: auxi@cib.csic.es

${ }^{1}$ Interdisciplinary Platform for Sustainable Plastics towards a Circular

Economy-of the Spanish National Research Council (SusPlast-CSIC), Madrid, Spain

Full list of author information is available at the end of the article
}

increase of $25 \%$ in 2024 compared to the previous 7 years [2]. One of the main alternatives in this field is the use of hydrogen as a substitute of hydrocarbons in internal combustion engines or in the production of electricity in fuel cells [3].

Hydrogen $\left(\mathrm{H}_{2}\right)$ is considered one of the most interesting fuels due to its high calorific value $(131 \mathrm{MJ} / \mathrm{kg})$, which is 2.6 and 6 times higher than gasoline and methanol, respectively, and the absence of $\mathrm{CO}_{2}$ emissions during its combustion $[4,5]$. Conventionally, hydrogen come from reforming stages of fossil fuels, covering $93 \%$ of the global demand of this compound in 2019 [5]. Hydrogen is also produced from water electrolysis (4\% of demand) and biotechnologically, so called biohydrogen (bio- $\left.\mathrm{H}_{2}\right)$, from the fermentation of $\mathrm{CO}_{2}$, sugars or volatile fatty original author(s) and the source, provide a link to the Creative Commons licence, and indicate if changes were made. The images or other third party material in this article are included in the article's Creative Commons licence, unless indicated otherwise in a credit line to the material. If material is not included in the article's Creative Commons licence and your intended use is not permitted by statutory regulation or exceeds the permitted use, you will need to obtain permission directly from the copyright holder. To view a copy of this licence, visit http://creativecommons.org/licenses/by/4.0/. The Creative Commons Public Domain Dedication waiver (http://creativeco mmons.org/publicdomain/zero/1.0/) applies to the data made available in this article, unless otherwise stated in a credit line to the data. 
acids (VFAs) by algae, bacteria or archaea in presence or absence of light [6].

The current $\mathrm{H}_{2}$ production methods pursue the reduction of the carbon footprint through the use of solar renewable energy in photovoltaic cells for water electrolysis (green hydrogen) and waste valorization, introducing new alternatives of management, where the biotechnological conversion plays a fundamental role [7]. Bio- $\mathrm{H}_{2}$ production has gained much attention due to its sustainability nature and less energy consumptive than physicochemical methods [6]. Moreover, dark fermentation is considered the most appropriate way, as it does not need any external energy, and reaches higher production rates over other procedures [5, 7]. With respect to other biofuels, bio- $\mathrm{H}_{2}$ has competitive advantages, such as the absence of carbon dioxide, other greenhouse gasses and pollutant particles upon combustion [8]. Hydrogen is also an energy carrier unlike the rest of carbon-based fuels, and represents the most abundant and lightest reactive gas, which is economical to produce and manufacture if specific routes are employed [8].

Rhodospirillum rubrum is a Gram-negative purple non-sulphur bacterium (PNSB), able to produce $\mathrm{H}_{2}$ by two different pathways, i.e., photofermentation of organic acids and carbohydrates, and via a water gas-shift reaction from $\mathrm{CO}$, a component of syngas $\left(\mathrm{CO}, \mathrm{CO}_{2}, \mathrm{H}_{2}\right)$ [9]. In the first pathway, light energy is essential to overcome the thermodynamic impediment of converting organic acids into $\mathrm{H}_{2}$ [7]. $\mathrm{H}_{2}$ is released as a secondary product of nitrogen fixation catalysed by a nitrogenase [10]. During the water gas-shift reaction, $\mathrm{CO}_{2}$ and $\mathrm{H}_{2}$ are produced because of water reduction by $\mathrm{CO}$ (Eq. 1):

$$
\mathrm{CO}+\mathrm{H}_{2} \mathrm{O} \rightarrow \mathrm{CO}_{2}+\mathrm{H}_{2} \text {. }
$$

This reaction is thermodynamically favourable $\left(\Delta G^{0}=-20 \mathrm{~kJ} / \mathrm{mol}\right)$ and requires the simultaneous activity of two enzymes, i.e., a carbon monoxide dehydrogenase $(\mathrm{CODH})$ and a hydrogenase [11]. In addition, ferredoxins $(\mathrm{Fd})$ act as electron transporters $[12$, 13]. The produced $\mathrm{CO}_{2}$ can be fixed by the Calvin-Benson-Bassham cycle (CBB) under photoautotrophic conditions [14]. More recently, the tricarboxylic acid cycle (TCA) and the ethylmalonyl-CoA cycle (EMCoA) have been identified as additional $\mathrm{CO}_{2}$ fixation routes in this bacterium $[15,16]$. Furthermore, $R$. rubrum is able to accumulate polyhydroxybutyrate (PHB) using syngas [16], sugars (e.g., fructose) and volatile fatty acids (VFAs) (e.g., formate, acetate, propionate, butyrate) as carbon sources [17-19]. From a techno-economic point of view, it has been demonstrated that syngas fermentation of $R$. rubrum is economically viable and technically feasible. The cost of producing the PHA via syngas fermentation is less expensive than producing PHA by sugar fermentation [20]. However, the operating cost of the biorefinery is heavily subsidized by the production and sale of the hydrogen gas, which has been counted as a co-product using $R$. rubrum [20]. Thus, guiding its metabolism towards the co-production of bio- $\mathrm{H}_{2}$ is of great interest.

The importance of PNSB as biocatalysts for $\mathrm{H}_{2}$ production is also based on their versatility to use VFAs and syngas, both derived from complex organic waste, as carbon and energy sources [21]. These transformations occur under mild operational conditions, i.e., temperatures around $30-40{ }^{\circ} \mathrm{C}$ and at atmospheric pressure, while the selectivity towards the desired products increases with respect to the chemical conventional processes [11]. In the case of syngas, the main fermentation challenge is to increase the transformation rate, limited by $\mathrm{CO}$ toxicity and its competition, in terms of affinity, by the active sites of the enzymes, with $\mathrm{O}_{2}$ and $\mathrm{CO}_{2}$ [21].

Most processes described so far that use $R$. rubrum to produce $\mathrm{H}_{2}$ from $\mathrm{CO}$ are performed under light conditions where an additional carbon source is used as the growth-limiting substrate, mainly acetate, which renders the highest biomass concentration [14]. The influence of $\mathrm{CO}$ transfer rate (COTR) by increasing the stirring or gas flow rate has been widely studied, and the optimal operational conditions yielded high $\mathrm{H}_{2}$ production rates in continuous regime $\left(32 \mathrm{mmol} \mathrm{H}_{2} \mathrm{l}^{-1} \mathrm{~h}^{-1}\right)$ [22].

In absence of light, $\mathrm{CO}$ is the growth-limiting substrate, but showed inhibition when the CO ratio exceeded 50\% of headspace in closed shaken bottles [12]. In this condition, although the cells were able to use $70 \%$ of the initial $\mathrm{CO}$, only $12 \%$ of the acetate was consumed at the end of the fermentation, yielding a low amount of biomass. In order to improve this process, we have demonstrated that $R$. rubrum does not require yeast extract for growing in the presence of $\mathrm{CO}$ and acetate [16]. Nevertheless, $R$. rubrum requires acetate to grow efficiently using $\mathrm{CO}$ as a sole carbon and energy source [16]. Recently, $R$. rubrum has been cultured at lab-bioreactor scale to produce PHB from syngas [15]. A combined C-P nutrient stress enhances the PHB cell content up to a $30 \% \mathrm{w} \mathrm{w}^{-1}$, with a productivity 5 times higher than the $\mathrm{C}$-limited condition, operating in fed-batch with acetate [15]. In both cases, the average $\mathrm{H}_{2}$ production rate was around $11 \mathrm{mmol} \mathrm{H}_{2} \mathrm{l}^{-1} \mathrm{~h}^{-1}$, feeding a syngas mixture with a $25 \%$ of $\mathrm{CO}$ [15].

Here, we show the optimal range of conditions necessary to produce $\mathrm{H}_{2}$ and PHB with $R$. rubrum at lab-bioreactor scale using $\mathrm{CO}$ in darkness, operating in a batch culture. Moreover, using a fed-batch regime by adapting the $\mathrm{CO}$ dose to bacterial growth, we have been able to increase the growth rate, yielding $27.2 \mathrm{mmol} \mathrm{H}_{2} \mathrm{l}^{-1} \mathrm{~h}^{-1}$ and reducing the operational time in 9 days. Finally, an 
empirical kinetic model has been proposed, capable to describe the evolution of every condition tested, both in batch or fed-batch operation modes. Our results improve the efficiency of $\mathrm{CO}$ into $\mathrm{H}_{2}$ by dark fermentation with R. rubrum in bioreactor and represent a starting point to explore further applications, such as the creation of "bio$\mathrm{H}_{2}$ fuel cells", fed only with $\mathrm{CO} / \mathrm{N}_{2}$ mixtures, operating with cultures of this microorganism in resting cells.

\section{Results and discussion}

\section{Study of the optimal bioreactor stirring speed to produce} $\mathrm{PHB}$ and $\mathrm{H}_{2}$ in a batch culture

The effect of stirring speed in batch cultures of $R$. rubrum is shown in Table 1. Enhancing CO transfer rate by stirring has not a positive effect over the bacterial growth, but it influences significantly the consumption of acetate and the final PHB production. The most remarkable results were obtained when we analysed the $\mathrm{PHB}$ and $\mathrm{H}_{2}$ yields with respect to $\mathrm{CO}$ concentration. Regardless of the selected speed stirring condition, the $\mathrm{CO}$ performance of these products remains constant, except in the case of PHB, where the yield decreased when the stirring speed is increased [22]. The tendency was also observed in the values of $\mathrm{H}_{2}$ productivity, considering the confidence intervals presented in Table 1.

The availability of $\mathrm{CO}$ has been reported as a limitation of $\mathrm{H}_{2}$ and $\mathrm{PHB}$ production in this process, due to the toxicity of high levels of dissolved $\mathrm{CO}(D C O)$ in $R$. rubrum $[22,23]$. The stirring speed increases the COTR by the volumetric mass transfer, $\mathrm{k}_{\mathrm{L}} \mathrm{a}$. However, this strategy causes cellular damage due to either a shear/hydrodynamic stress or an excess of the nutrient supply from the gas to the liquid phase [24, 25]. Surprisingly, R. rubrum cells experienced a great resistance to shear stress under aggressive stirring conditions (see data of runs conducted at 600 and $1000 \mathrm{rpm}$ in Table 1). This constitutes a novel and interesting response, since in other bioprocesses influenced by the gas-liquid mass transfer rate, the negative effect of hydrodynamic stress is observed in a similar range of stirring speed conditions studied in this work [26]. From these analyses, a stirring speed of $250 \mathrm{rpm}$ was selected as the optimal value for further experiments.

\section{Study of the initial CO partial pressure $\left(p_{\mathrm{co}}\right)$ to produce $\mathrm{PHB}$ and $\mathrm{H}_{2}$ in a batch culture}

To determine the influence of the initial concentration of $\mathrm{CO}$ in the bioreactor, seven batch runs were performed, employing different $p_{\mathrm{CO}}$ conditions: $0.10,0.20,0.40,0.50$, $0.60,0.75$ and $1.00 \mathrm{~atm}$. For each culture the final broth composition, regarding acetate concentration, biomass produced, specific growth rate, $\mathrm{CO}$ consumed and $\mathrm{H}_{2}-$ $\mathrm{CO}_{2}$ produced are shown in Table 2. The most remarkable changes occurred when the $p_{\mathrm{CO}}$ was increased above $0.20 \mathrm{~atm}$, where the acetate is completely consumed, the bacterial growth rate reached the highest value (around $0.06 \mathrm{~h}^{-1}$ ), yielding the maximum PHB accumulation (25$\left.30 \% \mathrm{w} \mathrm{w}^{-1}\right)$. In the gas phase, the water gas-shift reaction was unbalanced, which means that there was an important fraction of $\mathrm{CO}_{2}$ incorporated into cell metabolism (33-40\%). This ratio was maintained proving the ability of $R$. rubrum to assimilate $\mathrm{CO}_{2}$ in darkness $[15,16]$. The process was inhibited at $p_{\mathrm{CO}}$ of $1.00 \mathrm{~atm}$, according to the values of the growth rate and the batch time, although the cells were capable to consume high amounts of $\mathrm{CO}$, yielding more biomass (Table 2).

This tendency was also confirmed in the product yields values, shown in Fig. 1A-C. An equimolar 1:1 ratio was maintained in all the range studied for $\mathrm{H}_{2}$ (Fig. 1A, up to

Table 1 Experimental growth parameters, PHB cell content, product yields and productivities by using different stirring speed

\begin{tabular}{|c|c|c|c|c|}
\hline \multirow[t]{2}{*}{ Variable } & \multicolumn{4}{|c|}{ Stirring speed (rpm) } \\
\hline & 250 & 400 & 600 & 1000 \\
\hline$\mu_{\max }\left(\mathrm{h}^{-1}\right)$ & $0.057 \pm 0.005$ & $0.056 \pm 0.006$ & $0.055 \pm 0.005$ & $0.057 \pm 0.007$ \\
\hline$C_{x}\left(g^{-1}\right)$ & $1.46 \pm 0.08$ & $1.51 \pm 0.06$ & $1.57 \pm 0.15$ & $1.65 \pm 0.11$ \\
\hline PHB $\left(\% w w^{-1}\right)$ & $30.4 \pm 2.4$ & $25.7 \pm 1.7$ & $18.5 \pm 1.6$ & $17.1 \pm 1.5$ \\
\hline Batch time (h) & $140 \pm 5$ & $134 \pm 6$ & $101 \pm 4$ & $94 \pm 3$ \\
\hline$Y_{X / C O}\left(\mathrm{~g} \mathrm{~g}^{-1}\right)$ & $0.021 \pm 0.004$ & $0.022 \pm 0.005$ & $0.019 \pm 0.002$ & $0.023 \pm 0.007$ \\
\hline$Y_{X / A C}\left(g^{-1}\right)$ & $1.57 \pm 0.33$ & $1.48 \pm 0.21$ & $1.29 \pm 0.26$ & $1.03 \pm 0.19$ \\
\hline$Y_{\mathrm{PHB} / \mathrm{CO}}\left(\mathrm{g} \mathrm{g}^{-1}\right)$ & $0.008 \pm 0.0011$ & $0.007 \pm 0.0023$ & $0.003 \pm 0.0007$ & $0.001 \pm 0.0004$ \\
\hline$Y_{\mathrm{PHB} / \mathrm{AC}}\left(\mathrm{g} \mathrm{g}^{-1}\right)$ & $0.84 \pm 0.08$ & $0.78 \pm 0.05$ & $0.18 \pm 0.01$ & $0.13 \pm 0.02$ \\
\hline$Y_{\mathrm{H}_{2} / \mathrm{CO}}\left(\mathrm{g} \mathrm{g}^{-1}\right)$ & $0.071 \pm 0.006$ & $0.069 \pm 0.005$ & $0.07 \pm 0.008$ & $0.067 \pm 0.007$ \\
\hline$Y_{\mathrm{CO}_{2} / \mathrm{CO}}\left(\mathrm{g} \mathrm{g}^{-1}\right)$ & $1.01 \pm 0.11$ & $0.99 \pm 0.14$ & $1.03 \pm 0.16$ & $1.02 \pm 0.24$ \\
\hline$P_{\mathrm{PHB}} \times 10^{3}\left(\mathrm{gl}^{-1} \mathrm{~h}^{-1}\right)$ & $3.68 \pm 0.18$ & $3.09 \pm 0.15$ & $2.31 \pm 0.14$ & $1.08 \pm 0.10$ \\
\hline$P_{\mathrm{H}_{2}}\left(\mathrm{~g} \mathrm{l}^{-1} \mathrm{~h}^{-1}\right)$ & $0.038 \pm 0.005$ & $0.036 \pm 0.004$ & $0.031 \pm 0.006$ & $0.033 \pm 0.008$ \\
\hline
\end{tabular}


Table 2 Final broth and outlet gas composition in batch fermentations under several initial $p_{\mathrm{CO}}$ conditions

\begin{tabular}{|c|c|c|c|c|c|c|c|c|}
\hline \multirow[t]{2}{*}{$p_{\mathrm{CO}}(\mathrm{atm})$} & \multirow{2}{*}{$\begin{array}{l}\text { Acetate } \\
\text { Conversion (\%) }\end{array}$} & \multirow{2}{*}{$\begin{array}{l}\text { CO } \\
\text { Total uptake (mol) }\end{array}$} & \multicolumn{2}{|l|}{ Total biomass } & \multicolumn{2}{|l|}{ PHB } & \multicolumn{2}{|c|}{ Gases produced } \\
\hline & & & $\mu\left(\mathrm{h}^{-1}\right)$ & $C_{\mathrm{X}}\left(\mathrm{g} \mathrm{I}^{-1}\right)$ & $\begin{array}{l}\text { Cell content } \\
\left(\% w^{-1}\right)\end{array}$ & Titre $\left(\mathrm{gl}^{-1}\right)$ & $\mathrm{H}_{2}(\mathrm{~mol})$ & $\mathrm{CO}_{2}(\mathrm{~mol})$ \\
\hline 0.10 & $21.1 \pm 5.2$ & $1.05 \pm 0.12$ & $0.049 \pm 0.002$ & $0.36 \pm 0.04$ & $10.8 \pm 2.1$ & $0.04 \pm 0.01$ & $1.05 \pm 0.05$ & $0.99 \pm 0.09$ \\
\hline 0.20 & $37.4 \pm 4.3$ & $1.89 \pm 0.24$ & $0.058 \pm 0.006$ & $0.86 \pm 0.09$ & $14.8 \pm 0.8$ & $0.13 \pm 0.01$ & $1.81 \pm 0.16$ & $1.11 \pm 0.11$ \\
\hline 0.40 & $100 \pm 11.1$ & $2.71 \pm 0.26$ & $0.058 \pm 0.004$ & $1.32 \pm 0.11$ & $26.5 \pm 4.2$ & $0.31 \pm 0.01$ & $2.48 \pm 0.27$ & $1.57 \pm 0.17$ \\
\hline 0.50 & $100 \pm 5.2$ & $2.61 \pm 0.67$ & $0.057 \pm 0.005$ & $1.46 \pm 0.16$ & $30.4 \pm 2.4$ & $0.35 \pm 0.03$ & $2.59 \pm 0.13$ & $1.67 \pm 0.07$ \\
\hline 0.60 & $100 \pm 2.2$ & $4.57 \pm 0.41$ & $0.063 \pm 0.008$ & $1.74 \pm 0.21$ & $24.1 \pm 3.6$ & $0.38 \pm 0.06$ & $4.55 \pm 0.36$ & $2.76 \pm 0.22$ \\
\hline 0.75 & $100 \pm 2.7$ & $4.06 \pm 0.71$ & $0.061 \pm 0.007$ & $1.63 \pm 0.24$ & $24.8 \pm 2.3$ & $0.35 \pm 0.04$ & $3.96 \pm 0.41$ & $2.50 \pm 0.25$ \\
\hline 1.00 & $100 \pm 14.2$ & $4.94 \pm 2.41$ & $0.040 \pm 0.005$ & $2.06 \pm 0.54$ & $17.4 \pm 3.3$ & $0.32 \pm 0.09$ & $4.88 \pm 0.54$ & $3.22 \pm 0.35$ \\
\hline
\end{tabular}

the left). The evolution of $Y_{\mathrm{CO}_{2} / \mathrm{CO}}$ reinforces the idea of $\mathrm{CO}_{2}$ assimilation by $R$. rubrum: if initial $p_{\mathrm{CO}}$ was higher than $0.1 \mathrm{~atm}$, the yield decreases from 1 to $0.6 \mathrm{~mol} \mathrm{~mol}^{-1}$, which means that around $40 \%$ of this compound produced via water gas-shift reaction is being assimilated by the cells. PHB yields with respect to acetate and $\mathrm{CO}$ concentrations followed parallel tendencies (Fig. 1B, middle left). If the initial $\mathrm{CO}$ molar fraction increases, $Y_{\mathrm{PHB} / \mathrm{A}}$
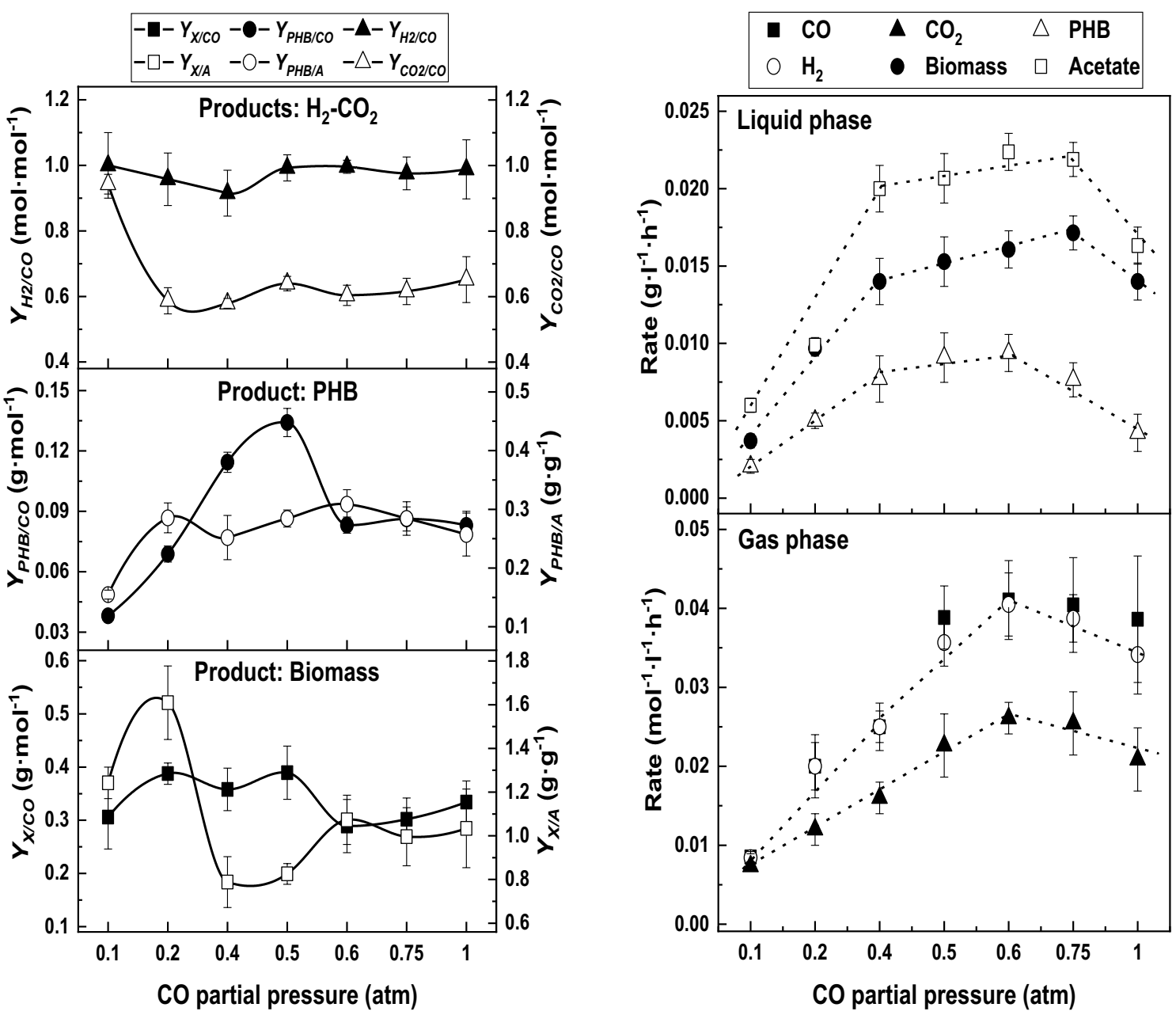

Fig. 1 Product yields (left) and maximum production or uptake rates (right) under different initial $p_{\text {CO }}$ conditions 

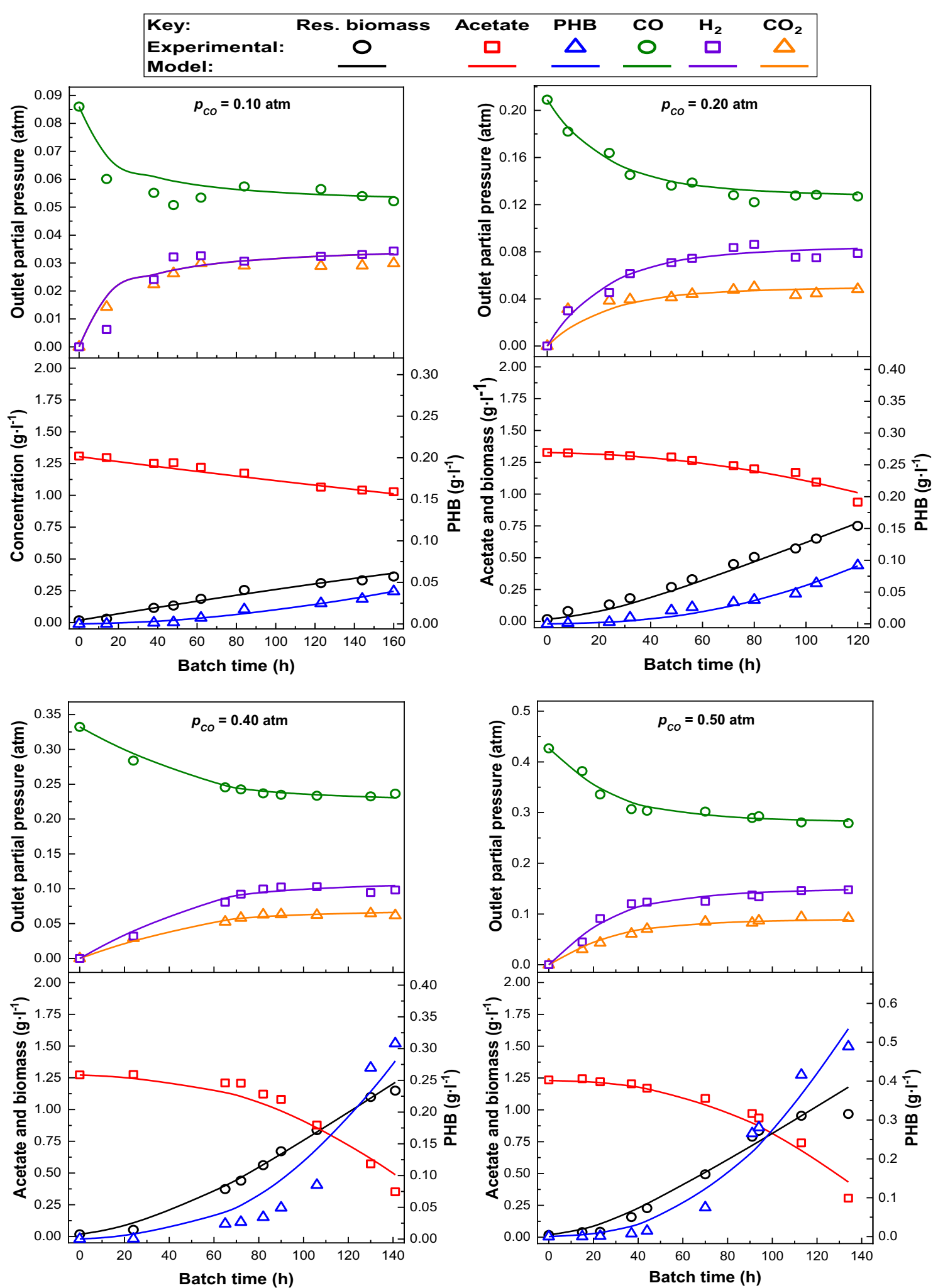

Fig. 2 Experimental and predicted data provided by the kinetic model under several initial $p_{C O}(0.10-0.50 \mathrm{~atm})$ 
Table 3 Kinetic and statistical parameters of the proposed model

\begin{tabular}{|c|c|c|c|c|c|c|c|c|}
\hline \multirow[t]{2}{*}{$p_{\mathrm{co}}(\mathrm{atm})$} & \multicolumn{8}{|c|}{ Kinetic parameter } \\
\hline & 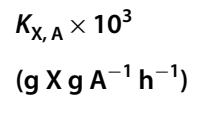 & $\begin{array}{l}\mathrm{K}_{\mathrm{X}, \mathrm{CO}_{2}} \\
(\mathrm{~g} \mathrm{X} \mathrm{mol} \\
\left.\mathrm{CO}_{2}^{-1} \mathrm{~h}^{-1}\right)\end{array}$ & $\begin{array}{l}K_{1} \\
\left(\mathrm{~mol} \mathrm{H}_{2} \mathrm{gX}^{-1} \mathrm{~h}^{-1}\right)\end{array}$ & $\begin{array}{l}K_{2} \times 10^{3} \\
\left(\mathrm{~mol} \mathrm{CO} \mathrm{g} \mathrm{X}^{-1}\right)\end{array}$ & $\begin{array}{l}K_{\mathrm{P}} \times 10^{3} \\
(\mathrm{gPHB} g \\
\left.\mathrm{X}^{-1} \mathrm{~h}^{-1}\right)\end{array}$ & $\begin{array}{l}\mathrm{U}_{\mathrm{A} / \mathrm{P}} \\
\left(\mathrm{g} \mathrm{A} \mathrm{g} \mathrm{PHB}{ }^{-1}\right)\end{array}$ & $\begin{array}{l}U_{A / X} \\
\left(g_{A g X^{-1}}\right)\end{array}$ & $\begin{array}{l}\mathrm{U}_{\mathrm{CO}_{2} / \mathrm{X}} \\
\left(\mathrm{g} \mathrm{CO}_{2} \mathrm{~g} \mathrm{X}^{-1}\right)\end{array}$ \\
\hline 0.10 & $2.01 \pm 0.51$ & - & $0.13 \pm 0.04$ & $0.65 \pm 0.21$ & $1.16 \pm 0.39$ & $0.25 \pm 0.04$ & $0.76 \pm 0.03$ & - \\
\hline 0.20 & - & $5.31 \pm 0.51$ & $0.26 \pm 0.03$ & $1.39 \pm 0.16$ & $2.18 \pm 0.74$ & $2.67 \pm 0.88$ & $0.12 \pm 0.04$ & $1.04 \pm 0.17$ \\
\hline 0.40 & - & $5.76 \pm 0.76$ & $0.18 \pm 0.02$ & $1.31 \pm 0.64$ & $3.95 \pm 0.74$ & $2.66 \pm 0.98$ & $0.09 \pm 0.03$ & $0.82 \pm 0.11$ \\
\hline 0.50 & - & $4.08 \pm 0.54$ & $0.34 \pm 0.04$ & $2.25 \pm 0.29$ & $7.79 \pm 2.29$ & $1.55 \pm 0.45$ & $0.04 \pm 0.02$ & $1.31 \pm 0.11$ \\
\hline 0.60 & - & $5.18 \pm 0.51$ & $0.21 \pm 0.01$ & $1.51 \pm 0.08$ & $5.92 \pm 0.95$ & $2.64 \pm 0.31$ & $0.26 \pm 0.03$ & $0.87 \pm 0.07$ \\
\hline 0.75 & - & $5.18 \pm 0.54$ & $0.18 \pm 0.02$ & $1.72 \pm 0.16$ & $6.03 \pm 0.99$ & $1,83 \pm 0.32$ & $0.52 \pm 0.02$ & $0.85 \pm 0.14$ \\
\hline 1.00 & - & $7.74 \pm 0.76$ & $0.08 \pm 0.01$ & $1.27 \pm 0.33$ & $1.52 \pm 0.11$ & $2.69 \pm 0.53$ & $0.18 \pm 0.04$ & $0.65 \pm 0.31$ \\
\hline \multirow[t]{2}{*}{$p_{\text {co }}($ atm $)$} & \multicolumn{8}{|c|}{ Statistical parameter } \\
\hline & $F_{\text {calc }}$ & $F_{\text {tab }}$ & RMSE & SSR & VE (\%) & & & \\
\hline 0.10 & 1529 & 2.249 & 0.002 & $2 \times 10^{-4}$ & 91.7 & & & \\
\hline 0.20 & 4399 & 2.249 & 0.003 & $6 \times 10^{-4}$ & 96.6 & & & \\
\hline 0.40 & 9066 & 2.249 & 0.003 & $5 \times 10^{-4}$ & 98.1 & & & \\
\hline 0.50 & 6314 & 2.249 & 0.005 & $1 \times 10^{-3}$ & 97.2 & & & \\
\hline 0.60 & 14,002 & 2.346 & 0.003 & $4 \times 10^{-4}$ & 99.3 & & & \\
\hline 0.75 & 24,872 & 2.249 & 0.003 & $6 \times 10^{-4}$ & 99.1 & & & \\
\hline 1.00 & 4426 & 2249 & 0.012 & $7 \times 10^{-3}$ & 90.1 & & & \\
\hline
\end{tabular}

reached a steady value around $0.30-0.35 \mathrm{~g} \mathrm{~g}^{-1}$. However, $Y_{\mathrm{PHB} / \mathrm{CO}}$ increased firstly up to a $p_{\mathrm{CO}}$ of 0.5 atm to further decrease and remain stable at $0.085 \mathrm{~g} \mathrm{~mol}^{-1}$. These results suggested that $\mathrm{PHB}$ is synthesized mainly from acetate at $p_{\mathrm{CO}}$ larger than 0.5 atm. Biomass yields with respect to the carbon sources evolved differently depending if the cells use $\mathrm{CO}$ or acetate (Fig. 1C, down left). In the first range of $p_{\mathrm{CO}}$ conditions (i.e., $0.1-0.5 \mathrm{~atm}$ ), $Y_{\mathrm{X} / \mathrm{CO}}$ value moved from 0.35 to $0.40 \mathrm{~g} \mathrm{~mol}^{-1}$, while at higher $D C O$ concentrations the $Y_{\mathrm{X} / \mathrm{CO}}$ value decreases slightly to $0.30 \mathrm{~g} \mathrm{~mol}^{-1}$. In the case of $Y_{\mathrm{X} / \mathrm{A}}$, the changes were observed at lower DCO (i.e., $p_{\mathrm{CO}}>0.20$ atm) and the decrease was very deep. This observation suggests a change in carbon source to produce biomass, i.e., $\mathrm{CO}_{2}$ started to be assimilated and the redirection of the acetate flow to PHB production (Fig. 1C).

The maximum values of production or consumption rates of the molecular species involved in the synthesis of $\mathrm{PHB}$ and $\mathrm{H}_{2}$ from syngas by $R$. rubrum are presented in Fig. 1D, E. The first section (Fig. 1D, up to the right) corresponds to the dynamics of the liquid phase. Three different regions can be defined with respect to $p_{\mathrm{CO}}$ condition. Firstly, from 0.1 to 0.4 atm of $\mathrm{CO}$ their values increase with $\mathrm{CO}$ pressure. Secondly, we observe an intermediate region from 0.5 to $0.75 \mathrm{~atm}$ of $p_{\mathrm{CO}}$, where these rates reach their maximum value. Finally, when $p_{\mathrm{CO}}$ is higher than $0.75 \mathrm{~atm}$ we observed an inhibition by an excess of $\mathrm{CO}$ causing a significant decrease in the values of PHB, biomass and acetate. In the case of the gas phase (Fig. 1E, down right), two different trends have been identified with respect to $\mathrm{CO}$ feeding: from 0.1 to $0.6 \mathrm{~atm}$ of $\mathrm{CO}$, every single rate increases with $p_{\mathrm{CO}}$, while if this variable is higher, an appreciable decrease of water gasshift reaction global rate has been observed.

From these observations a $p_{\mathrm{CO}}$ of 0.60 atm was selected as the optimal to cultivate $R$. rubrum in darkness. It provided the highest specific growth rate $\left(0.063 \mathrm{~h}^{-1}\right)$ and reached the maximum $\mathrm{PHB}$ production (around $26 \% \mathrm{w} \mathrm{w}^{-1}$ ) releasing $4.55 \mathrm{~mol}$ of $\mathrm{H}_{2}$, which was the most promising result if the consuming time for batch process is considered (117 vs. $222 \mathrm{~h}$, see below). Furthermore, under this $\mathrm{CO}$ concentration the acetate consumption rate was the highest observed in this study (less than 5 days were needed for a complete depletion, see above Fig. 2E).

\section{Kinetic model}

Kinetic and statistical model parameters values for the runs performed with different initial $\mathrm{CO}$ concentrations are shown in Table 3 . Their values reflect the tendencies observed in the culture when $p_{\mathrm{CO}}$ was increased, even in the gas or the liquid phase. Considering the growth, the kinetic constants do not present significant changes, showing their dependence on $\mathrm{CO}_{2}$ availability 

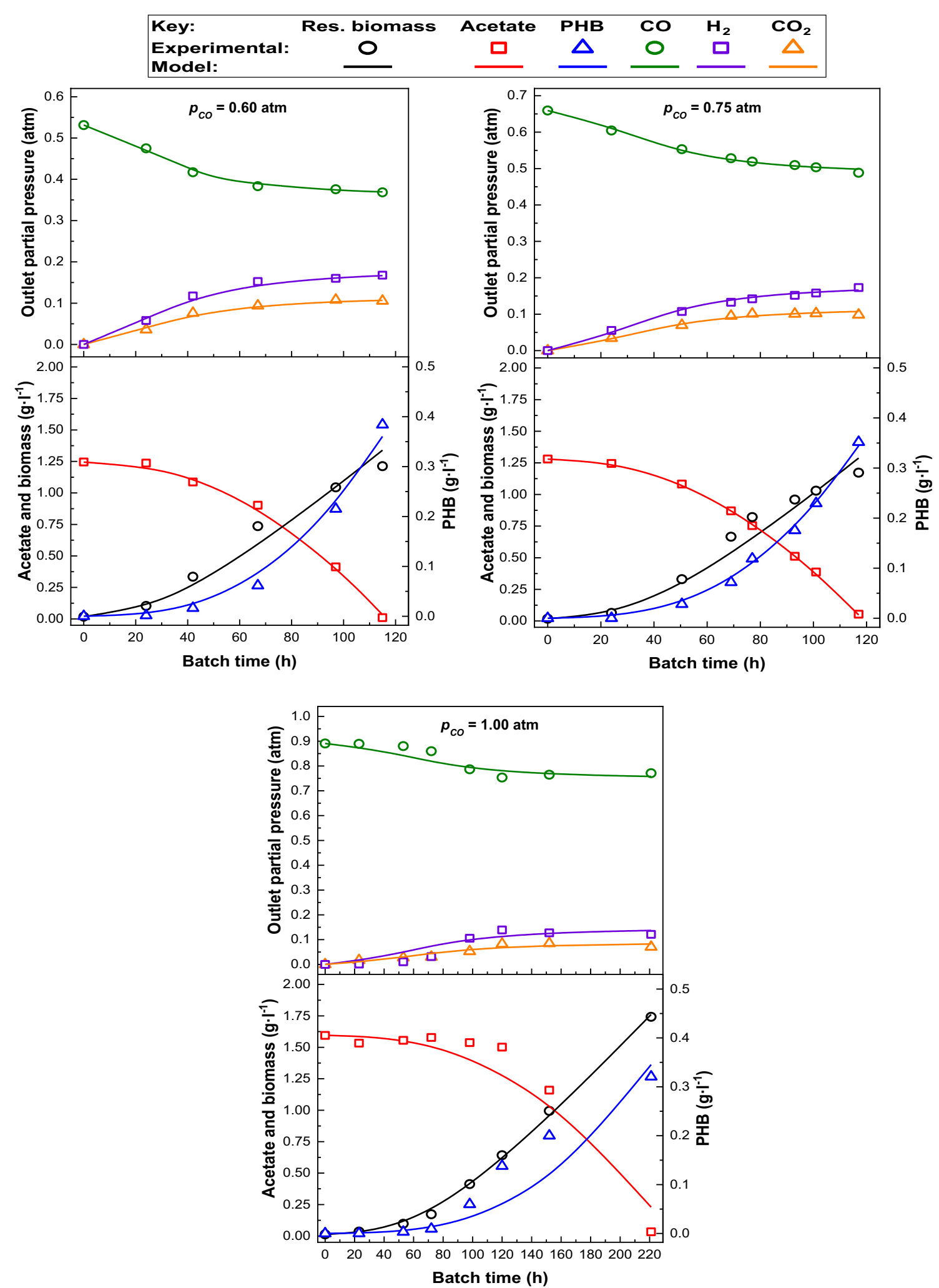

Fig. 3 Experimental and predicted data provided by the kinetic model under several initial $p_{\mathrm{CO}}(0.60-1.00 \mathrm{~atm})$ 
Table 4 Experimental results of the fed-batch runs performed under several CO-feeding strategies

\begin{tabular}{|c|c|c|c|c|c|c|c|}
\hline \multirow[t]{3}{*}{ CO-feeding strategy } & \multirow{3}{*}{$\begin{array}{l}\text { Operation time } \\
\text { (days) }\end{array}$} & \multicolumn{3}{|l|}{ Liquid phase } & \multirow{2}{*}{\multicolumn{3}{|c|}{$\begin{array}{l}\text { Gas phase } \\
\text { Avg. production- } \\
\text { consumption rates } \\
\left(\mathrm{mmol} \mathrm{I}^{-1} \mathrm{~h}^{-1}\right)\end{array}$}} \\
\hline & & \multirow[t]{2}{*}{ Total $C_{\mathrm{X}}\left(\mathrm{g} \mathrm{I}^{-1}\right)$} & \multirow[t]{2}{*}{$\begin{array}{l}\text { PHB (\%) } \\
\left(w w^{-1}\right)\end{array}$} & \multirow[t]{2}{*}{$\begin{array}{l}\text { Acetate } \\
\text { conversion (\%) }\end{array}$} & & & \\
\hline & & & & & $\mathrm{CO}$ & $\mathrm{H}_{2}$ & $\mathrm{CO}_{2}$ \\
\hline Constant $\left(p_{\mathrm{CO}}=0.60 \mathrm{~atm}\right)$ & 19.8 & 5.35 & 27.6 & 76.6 & 39.2 & 32.3 & 13.4 \\
\hline $\begin{array}{l}\text { Dynamic (from } 0.1 \text { to } 0.75 \mathrm{~atm} \text {, } \\
\text { enriching gas flow) }\end{array}$ & 10.8 & 4.28 & 24.9 & 91.4 & 29.1 & 27.2 & 15.3 \\
\hline $\begin{array}{l}\text { Dynamic (from } 0.1 \text { to } 2 \text { atm, } \\
\text { increasing working pressure) }\end{array}$ & 13 & 3.95 & 20.8 & 83.2 & 24.3 & 25.1 & 15.4 \\
\hline
\end{tabular}

in the medium. This performance matches with the values of the kinetic of $\mathrm{CO}_{2}$ yield with respect to biomass $\left(\mathrm{U}_{\mathrm{CO}_{2} / \mathrm{X}}\right)$. For the PHB production constant $\left(K_{\mathrm{P}}\right)$, the positive effect in the accumulation of this biopolymer when the $\mathrm{CO}$ availability was increased is also reflected in its values. This evolution was similar to that followed by the parameters involved in the water gas-shift reaction.

On the other hand, the kinetic yields of the conversion of acetate into PHB oscillate between 1.5 and 2.7 (note the carbon ratio 2:4 between acetate and 3-hydroxybutyrate). These values determine the distribution of this substrate with respect to biomass $\left(\mathrm{U}_{\mathrm{A} / \mathrm{X}}\right)$. According to the experimental observations of $\mathrm{CO}_{2}$ production rate (see also Fig. 1E), the kinetic yields of this compound with respect to biomass were maintained in a short range of values, which can suggest that the amount of this compound that is incorporated into the biomass was not dependent of the dissolved CO available for the cells.

All the fittings satisfy the statistical criteria explained below, reinforcing the validity of the proposed kinetic model: $F$-test, the root medium squared error (RMSE) and the variation explained (VE) reinforced the validity of the proposed kinetic model.

Experimental data and kinetic model predictions are presented in Figs. 2 and 3. The good fitting of the model is clearly observed, being able to reproduce the batch fermentation results. It is, therefore, a valid and robust approach to simulate the dynamics of this bioprocess in a wide range of operational conditions.

\section{Fed-batch experiments under different CO-feeding strategies}

The experimental results of the fed-batch runs are presented in Table 4. Furthermore, the evolution with time of the molecular species involved in gas and liquid phases together with the predicted curves given by the kinetic model are included in Fig. 4. Firstly, the optimal condition established in the previous section resulted inadequate in fed-batch regime (Fig. 4A, up to the left). After the first pulse of acetate, the experimental measurements clearly

Table 5 Comparative hydrogen production rate $\left(R_{\mathrm{H}_{2}}\right)$ in PNSB under photosynthetic or dark fermentation conditions

\begin{tabular}{|c|c|c|c|c|c|}
\hline Strain & Operation & Metabolic pathway & Carbon sources & $\begin{array}{l}R_{\mathrm{H}_{2}} \\
\mathrm{mmol} \mathrm{I}^{-1} \mathrm{~h}^{-1}\end{array}$ & References \\
\hline \multirow[t]{2}{*}{ Rhodopseudomonas palustris } & Batch & Photofermentation & Malate + glutamate & 0.3 & {$[43]$} \\
\hline & Batch & Photofermentation & Lactate & 2.2 & {$[44]$} \\
\hline \multirow[t]{3}{*}{ Rhodobacter sphaeroides } & Batch & Photofermentation & Acetate & 0.9 & {$[36]$} \\
\hline & Batch & Photofermentation & Acetate + butyrate + glutamate & 2.1 & {$[45]$} \\
\hline & Batch & Photofermentation & Acetate + butyrate + glutamate & 6.1 & {$[46]$} \\
\hline \multirow[t]{4}{*}{ Rhodobacter capsulatus } & Batch & Photofermentation & Glucose & 32 & {$[47]$} \\
\hline & Batch & Photofermentation & Acetate & 0.3 & {$[48]$} \\
\hline & Batch & Photofermentation & Acetate + butyrate & 0.2 & {$[49]$} \\
\hline & Batch & Photofermentation & Acetate + glutamate & 1 & {$[50]$} \\
\hline \multirow[t]{5}{*}{ Rhodospirillum rubrum } & Batch (light) & Syngas fermentation & Acetate + syngas & 0.2 & {$[13]$} \\
\hline & Continuous (light) & Syngas fermentation & Acetate + syngas & 32 & {$[22]$} \\
\hline & Fed-batch (dark) & Syngas fermentation & Acetate + syngas & 11 & {$[15]$} \\
\hline & Fed-batch (dark) & Syngas fermentation & Acetate + syngas & 27 & This work \\
\hline & Continuous & Photofermentation & Lactate + glutamate & 1 & {$[51]$} \\
\hline
\end{tabular}




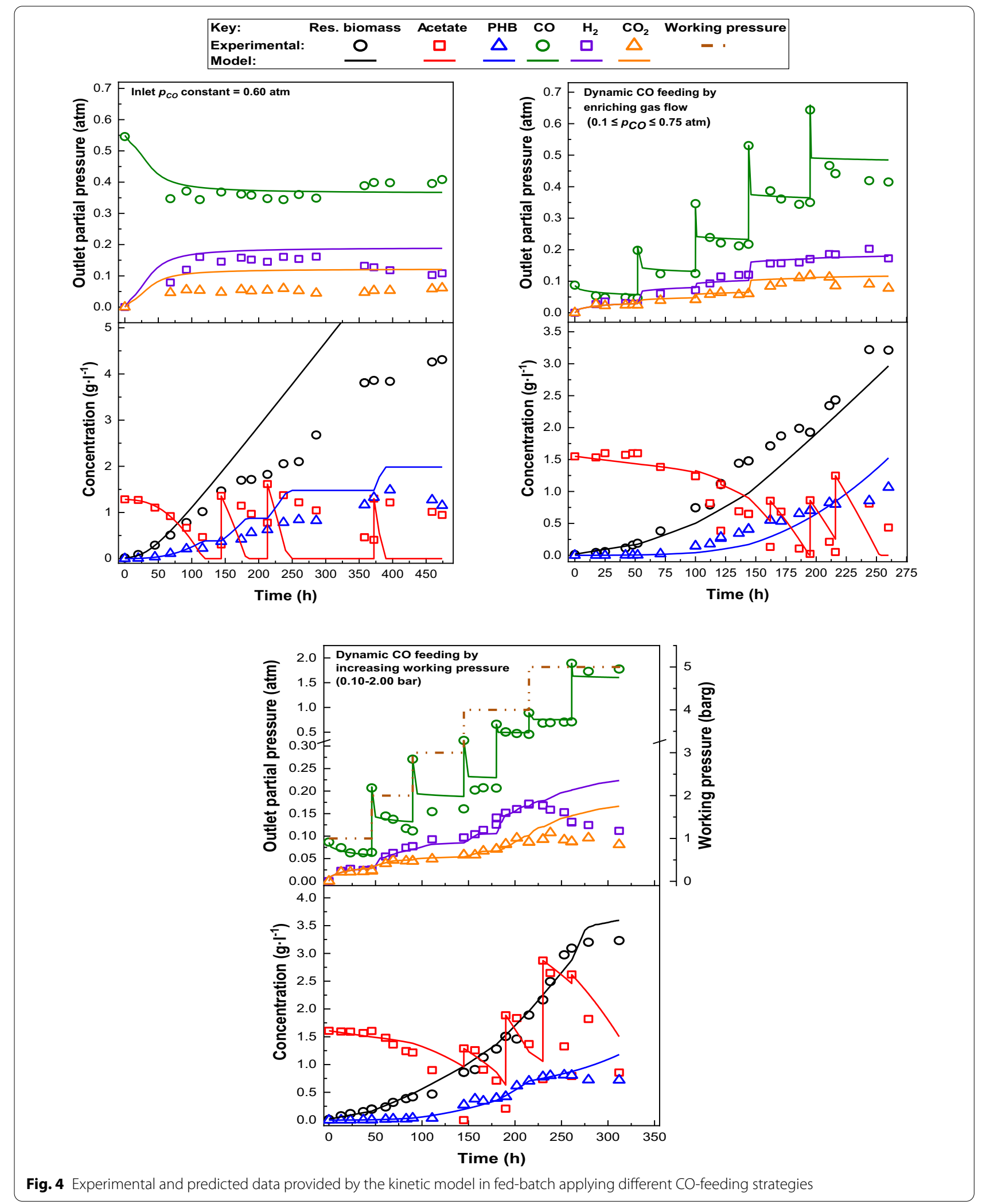




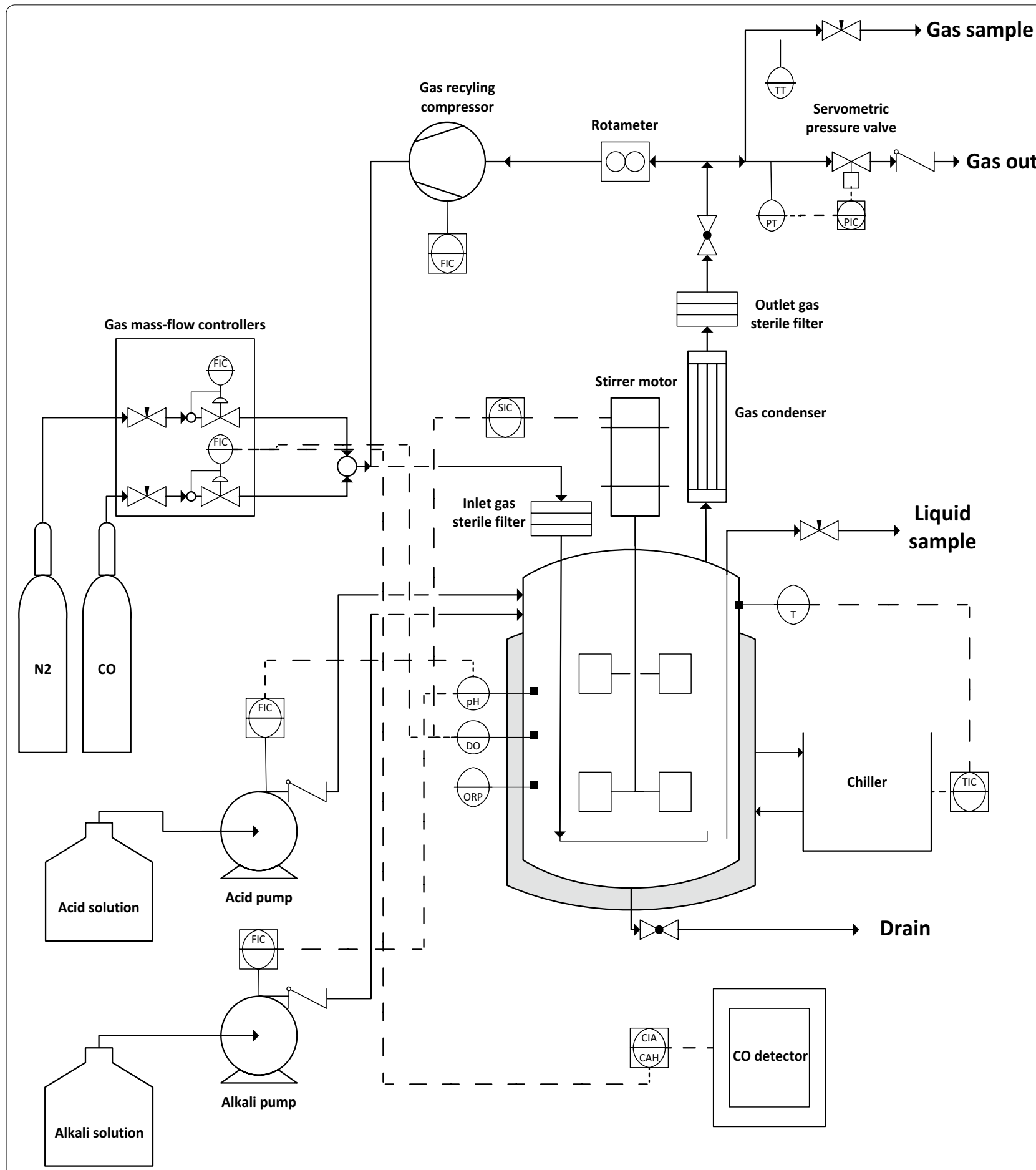

Fig. 5 Schematic layout of the tailor-made bioreactor unit for syngas fermentation

deviated from the predictions provided by the kinetic model. In this condition we reached the highest PHB and total biomass concentrations, whereas the COUR and
$R_{\mathrm{H}_{2}}$ average values were similar to the achieved in batch regime (Fig. 1E), but around 20 days were needed to reach these figures. Therefore, two additional alternatives 
Table 6 Simplified reaction network, kinetic equations and mass balances of the kinetic model proposed

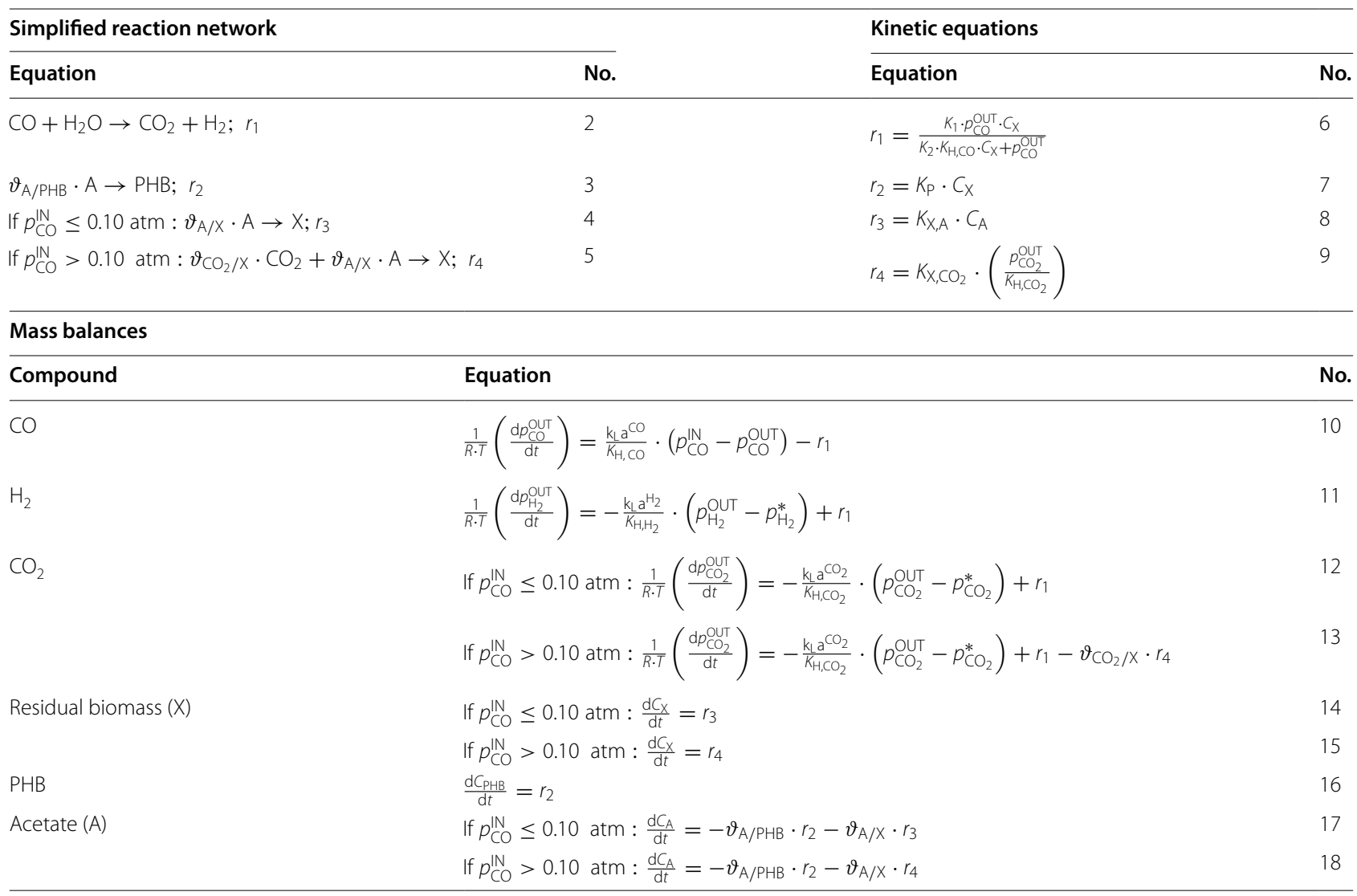

for operating in fed-batch regimes were explored, subsequently based on developing a dynamic CO supply to $R$. rubrum cultures, adapting the $\mathrm{CO}$ dose to the growth for avoiding $\mathrm{CO}$ toxicity and improving the use of the key substrates ( $\mathrm{CO}$ and acetate), while maintaining a high $\mathrm{H}_{2}$ production. According to the data shown in Table 4 and Fig. 4B, C, both dynamic CO-feeding strategies were beneficial to maintain the maximum growth rate. Moreover, the use of acetate was enhanced from 76 to $83 \%$ or $91 \%$, and the operation time was clearly reduced from 20 to 11 days or 13 days, respectively (Table 4). According to Table 5 , these procedures increased $\mathrm{H}_{2}$ production rates when compared to previous works operating in fed-batch with the same culture medium in darkness. In fact, our results were very close to those achieved with $R$. rubrum in continuous light cultures and other PNSB strains, with high $\mathrm{H}_{2}$ productivities by photofermentation of VFA's and sugars (Table 5 ). Furthermore, our bio- $\mathrm{H}_{2}$ productivity in fed-batch regime is comparable to others achieved with thermophilic microorganisms, such as Thermoanaerobacterium thermosaccharolyticum $\left(25.9 \mathrm{mmol} \mathrm{l}^{-1} \mathrm{~h}^{-1}\right)$ [27] or Thermotoga maritima $\left(28 \mathrm{mmol}^{-1} \mathrm{~h}^{-1}\right)$ [28].
The unique capability of $R$. rubrum to produce $\mathrm{H}_{2}$ and PHB from syngas and VFA's can be improved if a doubled $\mathrm{C}-\mathrm{P}$ nutrient limitation is induced, reaching a highest biopolymer accumulation of $30 \% \mathrm{w} \mathrm{w}^{-1}$ [15]. Monomer composition has been modified by using engineered strains containing genes of Pseudomonas putida or Cupriavidus necator (formerly Ralstonia eutropha) to produce co-polymers of 3-hydroxyoctanoate and 3-hydroxydecanoate or 3-hydroxybutyrate and 3-hydroxyvalerate, respectively $[29,30]$. In both cases the final PHA content was lower than the content achieved with the wild type strain in this work $\left(7.1 \%\right.$ and $14.8 \% \mathrm{w} \mathrm{w}^{-1}$, respectively) $[29,30]$. Other microorganisms can use syngas as carbon source, but they do not produce PHA naturally, such as clostridia [31]. However, by using recombinant strains of Clostridium coskatii, PHB was synthesized heterotrophically $\left(3.4 \% \mathrm{w} \mathrm{w}^{-1}\right)$ and autotrophically $\left(1.12 \mathrm{w} \mathrm{w}^{-1}\right)$ [32]. PHA producers were able to use the $\mathrm{CO}_{2}$ and $\mathrm{H}_{2}$ contained in syngas, but $\mathrm{CO}$ can only be catabolized when the cox subcluster found in some carboxydotrophic strains is heterologously expressed [31]. In this sense, promising results have been achieved in closed shaken 
bottles by introducing the cox genes of Oligotropha carboxidovorans in C. necator H16, achieving a final PHB cell content around $50 \% \mathrm{w} \mathrm{w}^{-1}$ [33].

Adapting the dose of $\mathrm{CO}$ to bacterial growth provided R. rubrum a greater tolerance to this compound (Fig. 4C). In the later stage of the run, the cells remain in exponential growth phase, even when the culture was subjected to 1 bar of $\mathrm{CO}$, a condition that was inhibitory in batch mode. This observation is interesting for further developing new strategies for $\mathrm{H}_{2}$ production from $\mathrm{CO}$ with this strain, applying the current $\mathrm{CO}$ dynamic dose in fedbatch to concentrate the culture in biomass and evaluating the $\mathrm{H}_{2}$ production capability without additional carbon sources (i.e., acetate).

\section{Conclusions}

The capability of co-producing $\mathrm{H}_{2}$ and $\mathrm{PHB}$ from $\mathrm{CO}$ under anaerobic conditions is unique in $R$. rubrum and therefore the use of this strain to produce $\mathrm{H}_{2}$ from $\mathrm{CO}$ by a dark fermentation has been evaluated at bioreactor scale. We have analysed the influence of the stirring speed, the initial $\mathrm{CO}$ partial pressure and the operation in batch and fed-batch regimes in order to optimize the production of $\mathrm{H}_{2}$. We have demonstrated that adapting the $\mathrm{CO}$ feeding to growth enhances the productivity reached in darkness by other strategies described so far, being similar to that obtained under light continuous syngas fermentations in other PNSB, yielding $27.2 \mathrm{mmol} \mathrm{H}_{2} \mathrm{l}^{-1} \mathrm{~h}^{-1}$. The kinetic model proposed was able to describe the experimental results obtained, even in batch or fed-batch regimes. Our results will pave the way to increase the production of bio- $\mathrm{H}_{2}$ that as commented above still represent a low fraction of the total $\mathrm{H}_{2}$ market. Moreover, this process allows the utilization of $\mathrm{CO}$ not only from conventional origins, such as gasification or steel mills, but also from most advanced processes such $\mathrm{CO}_{2}$ electrolysis or $\mathrm{CO}_{2}$ and water co-electrolysis.

The high efficiency of the water gas-shift reaction described in this study opens the possibility of exploring this transformation using different operational modes, for instance using resting cells instead of growing cells, whose format and simplicity can be exported to the creation of new fuel cells, producing bio- $\mathrm{H}_{2}$ from $\mathrm{CO}$ in a continuous operation.

\section{Methods}

\section{Bacterial strain, growth conditions and media}

R. rubrum S1 (ATCC 11170) was the strain used in this work. The strain was stored at $-80{ }^{\circ} \mathrm{C}$ in a $50 \%$ glycerolsaline serum solution closed vials. Before bioreactor inoculation, pre-cultures of this microorganism were grown in closed serum bottles inoculated with the frozen stock under anaerobic conditions $\left(\mathrm{CO} / \mathrm{N}_{2}, 50 / 50 \mathrm{~mol} \mathrm{~mol}^{-1}\right)$ on RRNCO medium (initial $\mathrm{pH}=7.0$ ) [12] supplemented with $15 \mathrm{mM}$ acetate at $30^{\circ} \mathrm{C}$ and $200 \mathrm{rpm}$ until the culture reaches the stationary phase (i.e., $\mathrm{OD}_{600} 1.2-1.5$ ). The RRNCO medium composition and the protocol followed to prepare the serum bottles have been described previously [16]. The initial optical density was fixed at 0.05 for both shaken bottles and bioreactors $[15,16]$. The pre-inoculum stage lasted between 7 and 10 days.

\section{Batch experiments in bioreactor: study of the optimal stirring speed and the initial $p_{\mathrm{co}}$}

The experiments with different initial CO concentrations were carried out in a 2-1 stainless steel tailor-made bioreactor. The schematic diagram of the experimental setup is shown in Fig. 5. The gas supply consists of two mass flow controllers (MFCs), represented as "flow indicator controllers" (FIC). The working pressure is controlled by a servometric value in the outlet gas stream (PIC), programmed to work between 1 and 5 barg. The unit is place inside an extractor hood with continuous flux. The $\mathrm{CO}$ detector acts over the inlet $\mathrm{CO}$-line through a controller (CIA-CAH), in order to ensure the work safety conditions. The working volume was $1 \mathrm{l}$ and $4 \%\left(\mathrm{v} \mathrm{v}^{-1}\right)$ inoculum from a stationary phase grown pre-culture, as indicated above [15]. The vessel was sterilized by autoclaving at $121{ }^{\circ} \mathrm{C}$ for $20 \mathrm{~min}$ before inoculation. The operational conditions are indicated as follows: $30{ }^{\circ} \mathrm{C}$ of temperature, $0.1 \mathrm{vvm}\left(100 \mathrm{ml} \mathrm{min}^{-1}\right)$ of total $\mathrm{CO} / \mathrm{N}_{2}$ inlet gas flow and the $\mathrm{pH}$ maintained around $7.0-7.2$ by adding periodic syringe pulses of $10 \mathrm{M} \mathrm{NaOH}$ [22]. For stirring studies, the stirrer speed was modified from 250 to $1000 \mathrm{rpm}[14,34]$. Once its optimal value was selected, the influence of initial $p_{\mathrm{CO}}$ was determined varying the inlet gas stream composition from 0.1 to $1 \mathrm{~atm}$ of $\mathrm{CO}$, operating under atmospheric working pressure (1 atm). All runs have been performed by triplicate.

\section{Fed-batch experiments in bioreactor: adapting CO dose in the gas phase to optimize growth and hydrogen production}

Fed-batch experiments were carried out using the same operational conditions of batch runs (i.e., temperature, optimal stirring speed, gas flow, $\mathrm{pH}$ and initial biomass concentration). Pulses of acetate were added periodically from $1 \mathrm{M}$ acetate solution. The CO supply in the gas stream was changed by: (i) maintaining the initial $p_{\mathrm{CO}}$ in a constant value, according to the optimal condition determined in the prior study; (ii) increasing the inlet gas stream in $\mathrm{CO}$ according to the bacterial growth from 10 
to $75 \%$ of the total gas flow $\left(100 \mathrm{ml} \mathrm{min}^{-1}\right)$; (iii) enriching the $\mathrm{CO}$ content in the culture medium by increasing the working pressure inside the vessel from 1 to 5 barg.

\section{Analytical methods \\ Biomass quantification and substrate monitoring in the liquid phase}

The concentration of biomass $\left(C_{\mathrm{X}}\right)$ was measured by optical density at $600 \mathrm{~nm}$ (Shimadzu UV-visible spectrophotometer UV-1603, Japan), correlating the sample absorbance $\left(\mathrm{OD}_{600}\right)$ with cell dry biomass $\left(\mathrm{g} \mathrm{l}^{-1}\right)$ according to Eq. (2) [35]:

$$
C_{\mathrm{X}}\left(\mathrm{g} \mathrm{L}^{-1}\right)=0.3488 \times \mathrm{OD}_{600} .
$$

Acetate concentration during syngas fermentation was determined by HPLC (Agilent Technologies 1200 Infinity II series, USA), using an Aminex HPX-87H C column $(300 \times 7.8 \mathrm{~mm}$, Bio-Rad, USA), coupled to a 1260 Infinity II Diode Array and Refractive Index Detectors, working at room temperature. The mobile phase employed was $0.005 \mathrm{M} \mathrm{H}_{2} \mathrm{SO}_{4}$ at flow rate of $0.5 \mathrm{ml} \mathrm{min}{ }^{-1}$. Column temperature was controlled at $50{ }^{\circ} \mathrm{C}$ and the sample volume was $15 \mu \mathrm{l}[16,35]$.

\section{Gas analysis}

The analytical protocol for $\mathrm{H}_{2}, \mathrm{CO}$ and $\mathrm{CO}_{2}$ quantification has been described elsewhere [16]. Gas samples from the headspace in serum bottles or the outlet gas stream in the bioreactor runs were taken from the cultures at different times and transferred to headspacevials, where a known fraction of $\mathrm{Ne}\left(p_{\mathrm{Ne}}=0.25\right.$ bar $)$, used as the internal gas standard, was added. Calibration curves of $\mathrm{H}_{2}, \mathrm{CO}_{2}$ and $\mathrm{CO}$ were performed by representing the ratio of the partial pressures of the compounds and the internal standard $\left(p_{\mathrm{i}} / p_{\mathrm{Ne}}\right)$ with respect to the ratio of areas provided by the chromato$\operatorname{gram}\left(A_{\mathrm{i}} / A_{\mathrm{Ne}}\right)$.

\section{Biopolymer quantification by GC/MS analysis}

The PHB content was measured by GC/MS determining the fraction of the methanolysed biopolymer by using a described protocol [16]. A standard curve from 0.5 to $2 \mathrm{mg}$ of PHB (Sigma-Aldrich) was used to interpolate sample data [36].

\section{Mathematical methods}

\section{$\mathrm{CO}, \mathrm{H}_{2}$ and $\mathrm{CO}_{2}$ mass balances}

Mass balances for the six compounds involved in syngas fermentation are shown in Table 6, through Eqs. (10-18).
The symbols " $\mathrm{k}_{\mathrm{L}} \mathrm{a}$ " are referred to the volumetric mass transfer coefficient for $\mathrm{CO}, \mathrm{CO}_{2}$ and $\mathrm{H}_{2}$, calculated through gas diffusivities [37]. " $K_{\mathrm{H}, \mathrm{I}}$ " is the value of Henry's constant for each compound in water, " $R$ " is the ideal gas law constant, " $T$ " is the working temperature and " $p_{\mathrm{i}} *$ " is the concentration in equilibrium with the liquid phase [26].

\section{Product yields, productivities and specific growth rates}

The analyses of the experimental results have been done by determining the following parameters: the product yield with respect to the substrate consumed $\left(Y_{i / j}\right.$,

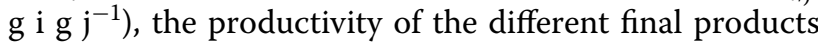
$\left(P_{i}, \mathrm{~g} \mathrm{i}^{-1} \mathrm{~h}^{-1}\right)$ and the specific biomass growth rate in each condition $\left(\mu, \mathrm{h}^{-1}\right)$ are defined by Eqs. (19-21), respectively:

$$
\begin{aligned}
& Y_{i / j}=\frac{C_{i, F}-C_{i, 0}}{C_{j, 0}-C_{j, F}}, \\
& P_{i}=\frac{C_{i, F}-C_{i, 0}}{t_{F}}, \\
& C_{\mathrm{X}}(t)=C_{\mathrm{X}, 0} \cdot \exp (\mu \cdot t) \rightarrow \ln \left(\frac{C_{\mathrm{X}}}{C_{\mathrm{X}, 0}}\right)=\mu \cdot t,
\end{aligned}
$$

where the sub-index " $F$ " refers to the final experimental time (h).

\section{Kinetic modelling: simplified reaction network}

The methodology developed to design the kinetic model proposed was described elsewhere for anaerobic bioprocesses [38, 39]. The kinetic model is represented in Table 6, according to Eqs. 2-5. The parameters " $v_{i / j}$ " represent the empirical yield of the product " $i$ " with respect to the substrate " $j$ ".

\section{Kinetic equations of the model reactions}

The kinetic equations of the proposed model are presented in Table 6, through Eqs. 6-9. All have been design according to the mass balances (see also Eqs. 10-18) [37].

\section{Calculation of kinetic parameters by fitting to experimental results}

The model was fitted to the experimental data using Aspen Custom Modeler (AspenTech, USA), considering six different responses: biomass, $\mathrm{CO}$, acetate, $\mathrm{PHB}$, hydrogen and $\mathrm{CO}_{2}$. Model parameters were estimated by minimizing the difference between experimental 
observations and model simulation according to "least squares method" by an adaptive non-linear least-squares algorithm (NL2SOL) [40]. Differential equations were integrated using an implicit Euler method, as previously described elsewhere [39, 41].

The validation of the fittings was performed based on of physicochemical and statistical criteria, including $F$-test $(F)$ for a $95 \%$ confidence interval, the sum of squared residuals (SSR), the residual mean squared error (RMSE) and the variation explained (VE) [41, 42]. These parameters are defined according to Eqs. 22-24, respectively:

$$
\begin{aligned}
& F=\frac{\sum_{i=1}^{N}\left(\frac{y_{i, \text { calc }}}{P}\right)^{2}}{\sum_{i=1}^{N} \frac{\text { SSR }}{N-P}}, \\
& \operatorname{RMSE}=\sqrt{\frac{\mathrm{SSR}}{N-P}}, \\
& \operatorname{VE}(\%)=100 \cdot\left(1-\frac{\sum_{l=1}^{L} \mathrm{SSQ}_{l}}{\sum_{l=1}^{L} \mathrm{SSQ}_{\text {mean }_{l}}}\right),
\end{aligned}
$$

where $N$ is the total number of experimental data, $P$ the number of parameters in the model; SSR the squared sum of residues and $y_{i \text {, calc }}$ the calculated values of the variable. $\mathrm{SSQ}_{l}$ and $\mathrm{SSQ}_{\text {mean }}$ are defined as follows [41]:

$$
\begin{aligned}
& \mathrm{SSQ}_{l}=\sum_{i=1}^{N} \frac{\left(y_{i, \text { exp }}-y_{i, \text { calc }}\right)^{2}}{y_{i, \text { calc }}^{\gamma l}}, \\
& \mathrm{SSQ}_{\text {mean }_{l}}=\sum_{i=1}^{N} \frac{\left(y_{i, \text { exp }}-\bar{y}_{i, \text { exp }}\right)^{2}}{y_{i, \text { calc }}^{\gamma l}},
\end{aligned}
$$

being

$$
\bar{y}_{i, \exp }=\frac{\sum_{i=1}^{N} \frac{y_{i, \text { exp }}}{y_{i, \text { calc }}^{\text {Yl/2 }}}}{\sum_{i=1}^{N} \frac{1}{y_{i, \text { calc }}^{\gamma l / 2}}},
$$

where " $\gamma_{j}$ " is the heteroscedasticity parameter, by means of the type of error in the measured variable. By default, Aspen Custom Modeler fixes its value at 1 .

\section{Abbreviations}

A: Acetate; $A_{i}$ : Chromatographic area of "i" compound; CBB: Calvin-BensonBassham cycle; CIA-CAA: CO detector and alarm actuator; CODH: Carbon monoxide dehydrogenase; COTR: Carbon monoxide transfer rate; COUR: Carbon monoxide uptake rate; $C_{X}$ : Biomass concentration; DCO: Dissolved carbon monoxide in the liquid phase; EMCoA: Ethylmalonyl-CoA; F: Fisher's parameter in F-test; Fd: Ferredoxin; FIC: Flow indicator controller; GC/MS: Gas chromatography coupled to mass spectrometry; HPLC: High-performance liquid chromatography; $\mathrm{K}_{1}: \mathrm{H}_{2}$ and $\mathrm{CO}_{2}$ production constant in the kinetic model; $K_{2}: \mathrm{H}_{2}$ and $\mathrm{CO}_{2}$ inhibition constant in the kinetic model; $K_{\mathrm{H}}:$ Henry's constant of compound " $\mathrm{i}$ "; $k_{\llcorner} \mathrm{a}$ : Volumetric gas-liquid mass transfer coefficient; $K_{\mathrm{p}}$ : PHB production constant in the kinetic model; $K_{\mathrm{X} / \mathrm{A}}$ : Acetate uptake constant in the kinetic model; $K_{\mathrm{X} / \mathrm{CO}_{2}}: \mathrm{CO}_{2}$ uptake constant in the kinetic model; MFCs: Mass flow controllers; NL2SOL: Adaptive non-linear squares algorithm; $\mathrm{OD}_{600}$ : Optical density measured at $600 \mathrm{~nm}$; PHB: Polyhydroxybutyrate; $p_{\mathrm{i}}$ : Partial pressure of compound " $\mathrm{i}$ " in inlet or outlet gas stream; $P_{i}$ : Productivity of compound "i"; PIC: Pressure indicator controller; PNSB: Purple non-sulphur bacteria; $R$ : Ideal gas law constant; $R_{\mathrm{i}}$ : Production or consumption rate of compound " $\mathrm{i}$ "; $r_{\mathrm{i}}$ : Chemical reaction in the proposed model; RMSE: Root medium squared error; SSR: Sum of squared residuals; T:Temperature; TCA: Tricarboxylic acid cycle; VE: Variation explained; VFAs: Volatile fatty acids; $Y_{i / j}$ : Experimental product "i" yield with respect to substrate "j".

\section{Greek symbols}

$\mu$ : Empirical product "i"yield with respect to substrate "j"; $v_{i / j}$ : Growth rate; $\gamma_{i}$ : Heteroscedasticity parameter in the kinetic model.

\section{Acknowledgements}

We thank the GC/MS Service of CIB-Margarita Salas and Ana Valencia Hernando for their excellent technical assistance.

\section{Authors' contributions}

AR: investigation, conceptualization, methodology, software, formal analysis, writing - original draft. $\mathrm{NH}-\mathrm{H}$ : investigation, methodology, formal analysis, review and editing. JLG: conceptualization, review and editing. MAP: conceptualization, supervision, writing — review and editing, funding acquisition, project administration. All authors read and approved the final manuscript.

\section{Funding}

The European Union's Horizon 2020 research and innovation program under grant agreement no. 679050 (CELBICON), the Community of Madrid (P2018/ NMT4389) and the Spanish Ministry of Science, Innovation and Universities (BIO2017-83448-R) supported this work.

\section{Availability of data and materials}

All data generated during this work are included in this publication.

\section{Ethics approval and consent to participate}

Not applicable.

\section{Consent for publication}

Not applicable.

\section{Competing interests}

The authors declare that they have no competing interests.

\section{Author details}

${ }^{1}$ Interdisciplinary Platform for Sustainable Plastics towards a Circular Economyof the Spanish National Research Council (SusPlast-CSIC), Madrid, Spain. 2Polymer Biotechnology Group, Department of Plant and Microbial Biotechnology, Biological Research Center, Margarita Salas"-CSIC, 28040 Madrid, Spain. ${ }^{3}$ Environmental Biotechnology Group, Department of Plant and Microbial Biotechnology, Biological Research Center, Margarita Salas"-CSIC 28040, Madrid, Spain.

Received: 30 May 2021 Accepted: 24 July 2021

Published online: 06 August 2021

\section{References}

1. Chiaramonti D, Talluri G, Scarlat N, Prussi M. The challenge of forecasting the role of biofuel in EU transport decarbonisation at 2050: a metaanalysis review of published scenarios. Renew Sustain Energy Rev. 2021;139:110715

2. Anejionu OCD, Di Lucia L, Woods J. Geospatial modelling of environmental and socioeconomic impacts of large-scale production of advanced biofuel. Biomass Bioenergy. 2020;142:105789.

3. Ambaye TG, Vaccari M, Bonilla-Petriciolet A, Prasad S, van Hullebusch ED, Rtimi S. Emerging technologies for biofuel production: a critical review 
on recent progress, challenges and perspectives. J Environ Manag. 2021:290:112627.

4. Łukajtis R, Hołowacz I, Kucharska K, Glinka M, Rybarczyk P, Przyjazny $A$, et al. Hydrogen production from biomass using dark fermentation. Renew Sustain Energy Rev. 2018;91:665-94.

5. Maggio G, Nicita A, Squadrito G. How the hydrogen production from RES could change energy and fuel markets: a review of recent literature. Int J Hydrog Energy. 2019;44:11371-84.

6. Chandrasekhar K, Kumar S, Lee B-D, Kim S-H. Waste based hydrogen production for circular bioeconomy: current status and future directions. Bioresour Technol. 2020;302:122920.

7. Stephen AJ, Archer SA, Orozco RL, Macaskie LE. Advances and bottlenecks in microbial hydrogen production. Microb Biotechnol. 2017:10:1120-7.

8. Zore UK, Yedire SG, Pandi N, Manickam S, Sonawane SH. A review on recent advances in hydrogen energy, fuel cell, biofuel and fuel refining via ultrasound process intensification. Ultrason Sonochem. 2021;73:105536.

9. Zhu H, Wakayama T, Asada Y, Miyake J. Hydrogen production by four cultures with participation by anoxygenic phototrophic bacterium and anaerobic bacterium in the presence of $\mathrm{NH} 4+$. Int $\mathrm{J}$ Hydrog Energy. 2001:26:1149-54.

10. Keskin T, Hallenbeck PC. Hydrogen production from sugar industry wastes using single-stage photofermentation. Bioresour Technol. 2012;112:131-6.

11. Molitor B, Richter $H$, Martin ME, Jensen RO, Juminaga A, Mihalcea C, et al. Carbon recovery by fermentation of CO-rich off gases-turning steel mills into biorefineries. Bioresour Technol. 2016;215:386-96.

12. Kerby RL, Ludden PW, Roberts GP. Carbon monoxide-dependent growth of Rhodospirillum rubrum. J Bacteriol. 1995;177:2241-4.

13. Najafpour $G$, Younesi $H$, Mohamed AR. Effect of organic substrate on hydrogen production from synthesis gas using Rhodospirillum rubrum in batch culture. Biochem Eng J. 2004:21:123-30.

14. Najafpour GD, Younesi H. Bioconversion of synthesis gas to hydrogen using a light-dependent photosynthetic bacterium, Rhodospirillum rubrum. World J Microbiol Biotechnol. 2007;23:275-84.

15. Karmann S, Panke S, Zinn M. Fed-batch cultivations of Rhodospirillum rubrum under multiple nutrient-limited growth conditions on syngas as a novel option to produce Poly(3-hydroxybutyrate) (PHB). Front Bioeng Biotechnol. 2019:7:59.

16. Revelles O, Tarazona N, García JL, Prieto MA. Carbon roadmap from syngas to polyhydroxyalkanoates in Rhodospirillum rubrum. Environ Microbiol. 2016;18:708-20.

17. De Meur Q, Deutschbauer A, Koch M, Bayon-Vicente G, Cabecas Segura P, Wattiez R, et al. New perspectives on butyrate assimilation in Rhodospirilum rubrum S1H under photoheterotrophic conditions. BMC Microbiol. 2020:20:126.

18. Xu C-R, Wu P, Lang L, Liu R-J, Li J-Z, Ji Y-B. Magnesium ions improving the growth and organics reduction of Rhodospirillum rubrum cultivated in sewage through regulating energy metabolism pathways. Water Sci Technol. 2015:72:472-7.

19. Do YS, Smeenk J, Broer KM, Kisting CJ, Brown R, Heindel TJ, et al. Growth of Rhodospirillum rubrum on synthesis gas: conversion of $\mathrm{CO}$ to $\mathrm{H} 2$ and poly- $\beta$-hydroxyalkanoate. Biotechnol Bioeng. 2007;97:279-86.

20. Choi D, Chipman DC, Bents SC, Brown RC. A techno-economic analysis of polyhydroxyalkanoate and hydrogen production from syngas fermentation of gasified biomass. Appl Biochem Biotechnol. 2010;160:1032-46.

21. Sun $X$, Atiyeh HK, Huhnke RL, Tanner RS. Syngas fermentation process development for production of biofuels and chemicals: a review. Bioresour Technol Rep. 2019;7:100279.

22. Younesi H, Najafpour G, Ku Ismail KS, Mohamed AR, Kamaruddin AH. Biohydrogen production in a continuous stirred tank bioreactor from synthesis gas by anaerobic photosynthetic bacterium Rhodospirillum rubrum. Bioresour Technol. 2008;99:2612-9.

23. Karmann S, Follonier S, Egger D, Hebel D, Panke S, Zinn M. Tailor-made PAT platform for safe syngas fermentations in batch, fed-batch and chemostat mode with Rhodospirillum rubrum. Microb Biotechnol. 2017:10:1365-75

24. Escobar S, Rodríguez A, Gómez E, Alcón A, Santos VE, García-Ochoa F. Influence of oxygen transfer on Pseudomonas putida effects on growth rate and biodesulfurization capacity. Bioprocess Biosyst Eng. 2016:39:545-54.

25. Rodríguez A, Ripoll V, Santos VE, Gómez E, García-Ochoa F. Effect of fluid dynamic conditions on 2,3-butanediol production by Raoultella terrigena in SBTR: oxygen transfer and uptake rates. J Chem Technol Biotechnol. 2017;92:1266-75.

26. García-Ochoa F, Gómez E, Santos Mazorra V, Merchuk J. Oxygen uptake rate in microbial processes: an overview. Biochem Eng $\mathrm{J}$. 2010:49:289-307.

27. Zhang K, Ren N-Q, Cao G-L, Wang A-J. Biohydrogen production behavior of moderately thermophile Thermoanaerobacterium thermosaccharoIyticum W16 under different gas-phase conditions. Int J Hydrog Energy. 2011;36:14041-8.

28. Saidi R, Liebgott PP, Hamdi M, Auria R, Bouallagui H. Enhancement of fermentative hydrogen production by Thermotoga maritima through hyperthermophilic anaerobic co-digestion of fruit-vegetable and fish wastes. Int J Hydrog Energy. 2018;43:23168-77.

29. Heinrich D, Raberg M, Philipp F, Kenny S, Morales-Gámez L, Babu R, et al. Synthesis gas (syngas)-derived medium-chain-length polyhydroxyalkanoate synthesis in engineered Rhodospirillum rubrum. Appl Environ Microbiol. 2016;82:6132-40

30. Heinrich D, Raberg M, Steinbüchel A. Synthesis of poly(3-hydroxybutyrate-co-3-hydroxyvalerate) from unrelated carbon sources in engineered Rhodospirillum rubrum. FEMS Microbiol Lett. 2015;362:8.

31. Drzyzga O, Revelles O, Durante-Rodríguez G, Díaz E, García JL, Prieto A. New challenges for syngas fermentation: towards production of biopolymers. J Chem Technol Biotechnol. 2015;90:1735-51.

32. Flüchter $S$, Follonier $S$, Schiel-Bengelsdorf B, Bengelsdorf FR, Zinn $M$, Dürre P. Anaerobic production of poly(3-hydroxybutyrate) and its precursor 3-hydroxybutyrate from synthesis gas by autotrophic Clostridia. Biomacromol. 2019;20:3271-82.

33. Heinrich D, Raberg M, Steinbüchel A. Studies on the aerobic utilization of synthesis gas (syngas) by wild type and recombinant strains of Ralstonia eutropha H16. Microb Biotechnol. 2018;11:647-56.

34. Ismail KSK, Najafpour G, Younesi H, Mohamed AR, Kamaruddin AH. Biological hydrogen production from CO: bioreactor performance. Biochem Eng J. 2008;39:468-77.

35. Mongili B, Fino D. Carbon monoxide fermentation to bioplastic: the effect of substrate adaptation on Rhodospirillum rubrum. Biomass Convers Biorefin. 2021;11:705-14.

36. Kim M-S, Kim D-H, Son H-N, Ten LN, Lee JK. Enhancing photo-fermentative hydrogen production by Rhodobacter sphaeroides KD131 and its PHB synthase deleted-mutant from acetate and butyrate. Int J Hydrog Energy. 2011;36:13964-71.

37. Mohammadi M, Mohamed AR, Najafpour GD, Younesi H, Uzir MH. Kinetic studies on fermentative production of biofuel from synthesis gas using Clostridium ljungdahlii. Sci World J. 2014;2014:910590.

38. De La Torre Pascual I, Ladero M, Santos Mazorra V. Production of D-lactic acid by Lactobacillus delbrueckii ssp. delbrueckii from orange peel waste: techno-economical assessment of nitrogen sources. Appl Microbiol Biotechnol. 2018;102(24):10511-21.

39. Rodríguez A, Wojtusik M, Masca F, Santos VE, García-Ochoa F. Kinetic modeling of 1,3-propanediol production from raw glycerol by Shimwellia blattae: influence of the initial substrate concentration. Biochem Eng J. 2017:117:57-65.

40. Dennis JE, Gay DM, Welsch RE. Algorithm 573: NL2SOL—an adaptive nonlinear least-squares algorithm [E4]. ACM Trans Math Softw. 1981;7:369-83.

41. Esteban J, Fuente E, Blanco Á, Ladero M, García-Ochoa F. Phenomenological kinetic model of the synthesis of glycerol carbonate assisted by focused beam reflectance measurements. Chem Eng J. 2015;260:434-43.

42. Ladero M, Gracia M, Tamayo J, Ahumada I, Trujillo F, García-Ochoa F. Kinetic modelling of the esterification of rosin and glycerol: application to industrial operation. Chem Eng J. 2011;169:319-28.

43. Basak N, Jana AK, Das D. CFD modeling of hydrodynamics and optimization of photofermentative hydrogen production by Rhodopseudomonas palustris DSM 123 in annular photobioreactor. Int J Hydrog Energy. 2016;41:7301-17.

44. Wu SC, Liou SZ, Lee CM. Correlation between bio-hydrogen production and polyhydroxybutyrate (PHB) synthesis by Rhodopseudomonas palustris WP3-5. Bioresour Technol. 2012;113:44-50. 
45. Ma $H$, Zheng $X$, Yang $H$. Enhancement on hydrogen production performance of Rhodobacter sphaeroides HY01 by overexpressing fdxN. Int J Hydrog Energy. 2018:43:17082-90.

46. Zheng X, Ma H, Zhang J, Yan W, Yang H. Improvement of photo-fermentative hydrogen production performance by expressing tetracycline resistance genes tetAR in Rhodobacter sphaeroides HY01. Int J Hydrog Energy. 2019;44:15823-32.

47. Ghosh D, Sobro IF, Hallenbeck PC. Optimization of the hydrogen yield from single-stage photofermentation of glucose by Rhodobacter capsulatus JP91 using response surface methodology. Bioresour Technol. 2012:123:199-206.

48. Özsoy Demiriz B, Kars G, Yücel M, Eroğlu I, Gündüz U. Hydrogen and poly-B-hydroxybutyric acid production at various acetate concentrations using Rhodobacter capsulatus DSM 1710. Int J Hydrog Energy. 2019;44:17269-77.
49. Ma C, Wang X, Guo L, Wu X, Yang H. Enhanced photo-fermentative hydrogen production by Rhodobacter capsulatus with pigment content manipulation. Bioresour Technol. 2012;118:490-5.

50. Zhang $Y$, Yang H, Guo L. Enhancing photo-fermentative hydrogen production performance of Rhodobacter capsulatus by disrupting methylmalonate-semialdehyde dehydrogenase gene. Int J Hydrog Energy. 2016;41:190-7.

51. Zürrer H, Bachofen R. Hydrogen production by the photosynthetic bacterium Rhodospirillum rubrum. Appl Environ Microbiol. 1979;37:789-93.

\section{Publisher's Note}

Springer Nature remains neutral with regard to jurisdictional claims in published maps and institutional affiliations.
Ready to submit your research? Choose BMC and benefit from:

- fast, convenient online submission

- thorough peer review by experienced researchers in your field

- rapid publication on acceptance

- support for research data, including large and complex data types

- gold Open Access which fosters wider collaboration and increased citations

- maximum visibility for your research: over $100 \mathrm{M}$ website views per year

At BMC, research is always in progress.

Learn more biomedcentral.com/submissions 